\title{
The Prospect of Electrical Enhanced Oil Recovery for Heavy Oil: A Review
}

\author{
M.K. Afdhol' ${ }^{1}$, T. Erfando' ${ }^{1}$ F. Hidayat ${ }^{1}$ M.Y. Hasibuan' ${ }^{1}$, S. Regina ${ }^{1}$ \\ 'Department of Petroleum Engineering, Faculty of Engineering, Universitas Islam Riau, Jalan Kaharuddin Nasution no. 113, \\ Simpang Tiga, Pekanbaru - 28284 \\ *Corresponding Author: afdhol@eng.uir.ac.id
}

\begin{tabular}{ll}
\hline \hline Article History: & Abstract \\
\hline $\begin{array}{l}\text { Received: April 27, 2020 } \\
\text { Acceive in Revised Form: July 8, } 2020\end{array}$ & $\begin{array}{l}\text { This paper presents a review of electrical heating for the recovery of heavy } \\
\text { oil which the work adopts methods used in the past and the prospects for } \\
\text { crude oil recovery in the future. Heavy oil is one of the crude oils with API } \\
\text { more than } 22 \text { which has the potential to overcome the current light oil } \\
\text { crisis. However, high viscosity and density are challenges in heavy oil }\end{array}$ \\
\hline Keywords: & $\begin{array}{l}\text { recovery. The method is often used to overcome these challenges by using } \\
\text { thermal injection methods, but this method results in economic and } \\
\text { efficiency, EOR }\end{array}$ \\
& $\begin{array}{l}\text { environmental issues. The electrical heating method could be a solution to } \\
\text { eplace conventional thermal methods in which the methodology of } \\
\text { electrical heating is to transfer heat into the reservoir due to increasing oil } \\
\text { mobility. Because the temperature rises, it could help to reduce oil } \\
\text { viscosity, then heavy oil will flow easily. The applications of electrical } \\
\text { heating have been adopted in this paper where the prospects of electrical } \\
\text { heating are carried out to be useful as guidelines of electrical heating. The } \\
\text { challenge of electrical heating is the excessive heat will damage the } \\
\text { formation that must be addressed in the prospect of electrical heating } \\
\text { which must meet energy efficiency. The use of Artificial intelligence } \\
\text { becomes a new technology to overcome problems that are often found in } \\
\text { conventional thermal methods where this method could avoid steam } \\
\text { breakthrough and excessive heat. Therefore, it becomes more efficient and } \\
\text { could reduce costs. }\end{array}$ \\
\hline \hline
\end{tabular}

\section{INTRODUCTION}

As energy resources, crude oil is widely used today in which the consumption is increasing every year, but oil production has been declining because the light oil has been extracted (Ado et al., 2018; Bientinesi et al., 2013; Rehman \& Meribout, 2012). Heavy oil reserve is 70\% of total world oil reserves (Mozafari \& Nasri, 2017), High viscosity and density are the issue of heavy oil which contains higher asphalt and sulfur components than conventional oil (M. Zhu et al., 2015). Therefore, it becomes a challenge to produce crude oil from the reservoir either technically or economically (Greff \& Babadagli, 2013). The challenges in producing heavy oil are the very high cost and the massive heat required to flow oil into the perforation, heavy oil also contains impurities that must be removed such as sulfur, heavy metal, waxes, and residue (Madhavan \& Mamora, 2010).

Most of the heavy oil deposited in deep formation comes from conventional oil which migrates to areas affected by bacteria and weathering (J. G. Speight, 2013). Therefore, a conventional method could not be applied in low API $(<20)$ reservoir (Hill, 2014), the solution to apply is steam or thermal injection into the reservoir which could reduce the viscosity of the heavy oil (Bera \& Babadagli, 2015).

There are two methods of reservoir heating which most of them are electrical heating and thermal injection. The applications of thermal or steam injection for heavy oil recovery have disadvantages related to economic and environmental issues. However, this method also could not be applied to the reservoir which has high clay contents, deep formations, and heterogeneous reservoirs (Sadeghi et al., 2017a). Electrical heating is one of the thermal methods by transferring heat into the reservoir, because the temperature rises, it could reduce oil viscosity and makes it easier for solid materials to flow. These effects could help in sweeping oil out of the formation when there is a media able to drive oil such as gravity drainage. The aim of the electrical heating method for heavy oil is to reduce oil viscosity due to heat transfer that increases oil mobility, and then crude oil could flow easily to the production well (Rehman \& Meribout, 2012). 
The applications of the electrical heating method utilize a heat transfer system using an electrode where the electrode will flow an electric current. The electric current will leave the electricity generator and flows downwards to the electrode that directly has electrical contact with reservoir formations. From the electrode, an electric current flow through the reservoir and flows back to the surface or power supply. The amount of required electric current depends on the rate of production because, when the hot water is producing, the colder fluid will be flowing from the reservoir to the well. If there is much energy used, it will give uncontrolled temperature and damages formation (Vinsome et al., 1994).

Critical research works have given a high impact on the application of electrical heating to have produced large oil cumulative for the enhanced oil recovery method. Currently, there are numerous active electrical heating for many EOR projects. The works adopt several electrical heating projects and applications in the world, where this research could be useful as guidelines to determine the electrical heating application that could be implemented in the future.

\section{ELECTRICAL HEATING MECHANISMS}

The mechanism of electrical heating is generally divided into two types, electrical heating for vertical well and horizontal well using a thermal process either to heat steam chamber or direct heating into the near-wellbore of the vertical well and horizontal well (Hassanzadeh et al., 2016; B C W McGee et al., 1999; T N Nasr et al., 2000; Yao et al., 2019). Electrical heating also applied the SAGD process heating the formation by gravity drainage (Yongbin et al., 2017; Yuan et al., 2004). The production rate and operational requirements will determine the amount of power required for electrical heating, depending on each well and formation. The more flow rate increases, the more electricity is required to compensate the flow rate. The process of the electrical heating system occurs while oil is produced, there is no fluid required for injecting the reservoir. Therefore, the formation of damage is negligible. Besides, the electrical heating is also applied for steam chamber-heating (B C W McGee et al., 1996), Brine and electrical energy affect the heating path due to heat conductivity, and most of the water or water saturation will decrease and form steam due to heat generated by electric current (Das, 2008).

The molecular movement may result in significouldt heating, and polar molecules tend to align and relax with the alternating electric field. Therefore, the frequency of the electric current could determine the types of electrical heating (Sahni et al., 2000). Figure 1 shows several important components in electric heating applications including the electrode assembly, ground return system, and even more power delivery and conditioning systems. To minimize the electrical heating losses and avoid localized heating using the delivery system is the right electrical heating design to use. Meanwhile, the purpose of the assembly contains bare casing which can optimize the effectiveness of heat in oil reservoirs using fiberglass electrical insulation. The casing and electrode connections in a single well system using an isolated electrode are the current system located on the string above fiberglass. The current flows from the power conditioning unit and conducts a power delivery system to the electrode assembly, then the current flows through oil formation and returns to the power cooling unit system. Therefore, oil viscosity could be reduced well by heating (B C W McGee et al., 1996). There are advantages of electrical heating which are there is no fluid injected, heating while producing at the same time, reducing heat loss, able to be applied into a reservoir containing clay swelling, and the efficiency of volumetric sweeping is greater than thermal injection because the electric current could flow in the low permeability.

\section{CONVENTIONAL METHOD FOR HEAVY OIL RECOVERY}

Reducing oil viscosity using the thermal injection method is the most widely applied method for heavy oil that is heating the reservoir to increase oil mobility. Therefore, more than $50 \%$ of total heavy oil projects apply the thermal method from all over the world, the most popular method for thermal injection applied in heavy oil reservoir is steam injection. Based on the screening criteria of steam injection, this method only could be applied in the reservoir which is at the shallow depth and has a high viscosity called heavy oil (Das, 2007; Santos et al., 2014; Thakur, 1997; Wehunt et al., 2003). Thermal injection requires to maintain the fluid inejction due to pressure required which fluid is injected continuously into the reservoir that displaces oil and obtains a higher production (J. G. Speight, 2013).

\section{Hot water injection}

Injecting hot water into the strata hydrocarbon could reduce the viscosity of heavy oil (Hascakir et al., 2008), therefore it will flow easily and could increase production because there is heat transfer between the heavy oil and hot water that occurs in the reservoir. A project in the middle eastern reservoir with large heavy oil deposits had a viscosity of $500 \mathrm{cp}$ where the hot water injection method increased oil recovery by $25 \%$. However, the disadvantage of hot water was less efficient due to less heat content compared to the steam injection method (Tawfik Noaman Nasr \& Ayodele, 2005). Abdurrahman et al (2018) suggested the more benefit of hot water injection is to apply into waxy-crude oilfield.

\section{Cyclic steam stimulation}

Currently, the method of heavy oil recovery using cyclic steam stimulation (CSS) has been adopted because CSS is one of the effective methods that is suitable to be applied in the reservoir which has a high viscosity such as bitumen, heavy oil, etc (Bao et al., 2017). The advantage of cyclic steam injection is that could inject steam with high pressure 
without fracturing any damage in the reservoir. Therefore, Cyclic steam injection is often applied to oil production with high viscosity. The application of CSS is usually at a depth formation, more than 1000 feet, however, it depends on the type and structure of the formations (Batycky et al., 1997). CSS has several disadvantages, one of which is a relatively low recovery factor that is around (26-35\%). The highest recovery factor of the CSS increases the recovery factor by about $40 \%$, but it is less effective than other thermal injection methods such as SAGD (60-70\%) and steam injection (50-60\%). However, CSS has the advantage of being more energy efficient with lower emission intensities than other thermal injection methods. For example, the results of the research on the application of CSS in the Melibur field, Padang-Indonesia which a reservoir contains heavy oil with viscosity 9-12 cP and 22-26 API gravity oil, showed that CSS is an effective recovery method used in the extra-heavy oil reservoir which significouldtly mizinimed heat losses from the surface and resulted low greenhouse gas emissions since there is no steam generator required. Besides, CSS also is more economically profitable. With CSS injections a few months to produce results that are quite maximum with a total of recovery factor of 40\% (Putra et al., 2011). CSS also has been done for paraffinic-type crude oil, and it shows some promising result (Hidayat \& Abdurrahman, 2018).

\section{Thermal injection}

Thermal recovery, or more specifically steam injection, is the most successful recovery technique used today to be applied to improve oil recovery (Ghoodjani et al., 2012; Melysa, 2016). The thermal injection could rapidly reduce oil viscosity, improve production substantially, and shifts rock wettability to conditions more favorable for oil recovery. Thermal recovery is commonly applied to heavy oil wells, but not all heavy oil could be applied for thermal injection. Thermal injection could also be applied to lighter oil and more heterogeneous formations (Dietz, 1975). The injection method is quite successful because it could increase oil recovery substantially. The heat transfer could sweep the side of the reservoir which never did oil have contact with the injection such as steam injection. However, the full benefit of it is also depending on the injection pattern used in this method. Kusumastuti et al (2019) found that inverted seven-spot will give the full benefit of recovery. Thermal injection could replace resources to reserves that thermal injection plays a crucial role in the development of heavy oil for the future projects, which one of them is electrical heating.

\section{Steam Assisted Gravity Drainage}

One of thermal injection that is also widely applied for heavy oil is steam-assisted gravity drainage called SAGD (Alvarado \& Manrique, 2010; Vincent et al., 2004). SAGD is a new technology applied to recover in high viscosity crude oil and has realized large-scale commercial applications through steam injection, cold oil is heated while the steam is condensed into the hot water (Giacchetta et al., 2015). The hot fluid is resulted by gravity drainage. SAGD could be applied in the reservoir using a combination of vertical well and horizontal well (Y. Wang et al., 2017), even the combination of the dual-horizontal well pattern that is the most popular of SAGD well pattern and the most common way in the SAGD project (Xi et al., 2017). The distinctiveness of SAGD is the counter-current flows, and the method adopts the disparate of other thermal methods that lie in the key role of moving boundaries (T N Nasr et al., 2000; Xiaoxiong et al., 2018). However, the high cost of SAGD projects still become an issue to applications in the heavy oil field for installation and steam (Carlson, 2003; Ji et al., 2016; Sood, 2016).

\section{In-Situ Combustion}

The study of in-situ combustion has been developed in many years due to increasing heavy oil recovery. This method requires the high control of large air volumes at high pressure for the combustion either forward or even reverse (Stinson et al., 1976). The in-situ method is to inject oxidizing gas into the reservoir that, sometimes, is using oxygenenriched air or only air to generate heat because there is a burning of oil portion to reduce oil viscosity. Therfore it could flow oil to the well easily that this method also be called thermal injection method. To sustain the flame front in the reservoir which requires air to ignition in the well. In this process a small portion of oil will ignite produces $\mathrm{CO} 2$, water vapor, and heat. The objectivity of thermal injection is to increase oil mobility by the heating method (Ali, 1982). The heat energy driven by in-situ is injecting gas containing oxygen into the reservoir to combustion method (Onyekonwu et al., 1986). Then, gas drive combination between steam and water drive which the gas comes from the combustion gases driving the oil into the production well through the reservoir. The heat generated in the surface before injecting into the reservoir is what distinguishes it from other thermal methods (Melcon, 1965).

Improving oil recovery using in-situ method has long been applied for heavy oil which could increase API $6^{\circ}$ to $20^{\circ}$ based on the field observations that apply combustion (Doraiah et al., 2007). In India (Gujarat) have applied in-situ combustion, located in Mehsana at the northern of Cambay Basin, which has several heavy oil fields with reserves of around 140 MMT OOIP and oil viscosity ranges from 50 to $450 \mathrm{cP}$. High mobility contrast between viscous oil and water makes the primary recovery low. The artificial lift method has been applied, but it makes water production higher than oil. Therefore, in-situ combustion techniques are applied to replace of artificial lift method. The application of in situ combustion in the Mehsana field was successfully implemented. Projects that began in 1991 could increase oil recovery factors from $6-12 \%$ to $39-45 \%$. 


\section{PAST AND CURRENT OF ELECTRICAL HEATING}

The transition of conventional oil that has a lower viscosity used today to the unconventional oil called heavy oil and bitumen is one of the potential crude oil used as a link to reduce the crisis of light oil sources that, however, exploiting heavy oil using steam injection is quite effective but not efficient to use because steam injection requires large energy consumption and produces substantial greenhouse gas emissions (Gates \& Larter, 2014). Electrical heating of EOR called Electrical-enhanced oil recovery (EEOR) could be an alternative method used than the conventional method of EOR. There are three fundamental heat transfers of the electrical heating method into the formation: heat conduction, heat convection, and radiation. Heat conduction transfers heat based on vibrations for each molecule contact, heat convection is heat transferred from the transfer of gas or liquid with the heat contained in the vicinity, and radiation is an energy-heating transferred through electromagnetic waves (Sandberg et al., 2014).

Electrical heating requires electricity sources, but this method could be applied for every situation and could be efficiently transferring heat for the entire reservoir with a big volume, which reservoir depth could be neglected (Bruce C W McGee \& Vermeulen, 2007; Zyrin \& Vasiliev, 2016). EEOR aims to reduce oil viscosity due to heat transfer that increases oil mobility, and then crude oil could flow to production well because electrical energy in the reservoir could raise the temperature and creates vibrations on hydrocarbon molecules (Rangel-German et al., 2004; Rehman \& Meribout, 2012).

\section{Hybrid Process}

The electrical heating project has been developed in many years and designed to replace or supplant another energy process such as SAGD (Z. Zhu et al., 2013). SAGD (steam-assisted gravity drainage) Process results in GHG Emission where the current limit is 100 million tones/year from oil sand operations and around $\$ 30 /$ ton carbon price. This method was tested in a sandbox, an induction loop embedded in the sandstone layer. The field projects had been planned since 2012, but never did it carry out (Hu et al., 2017; Koolman et al., 2008).

\section{Gas and electrical heating assisted gravity drainage}

Zhong et al (2011) represented the study which proposed the mechanism of gas and electrical heating gravity drainage (GEHGD) for resistance heating in both of vertical and horizontal well. In this study, the injection well was placed on the upper position or higher than lower horizontal well. A gas such as N2, CO2, flue gas, and natural gas was injected which the experimental study has shown a two-fold increase that oil rate increased by six-fold for an 1861 cP. Injecting gas using the principle of gravity drainage, GEHGD, is to reduce the fluid viscosity by injecting gas into the potential zone, and to manage the pressure that oil could flow down into the production zone. Therefore, it will increase the sweep efficiency and reach the higher recovery factor. Those principles could be seen in Figure 2.

The advantage of GEHGD is to increase the recovery of heavy oil production which initially had no potential to be potential. GEHGD could recover oil in the deeper zone and water sensitive such as the reservoir in the desert area which the gas could be injected using a compressor or directly inject using nitrogen separator, just only for nitrogen injection, Therefore the application of this method could be applied in the offshore platform due to no surface steam generator required and will reduce the capital and operating cost (Hassanzadeh et al., 2016).

\section{Electromagnetic Heating}

The electromagnetic heating (EM) process method is highly favorable for heavy oil recovery using the EOR method which generates heat volumes, called the eddy current loss. Eddy current is the induction of an electromagnetic field produced by an AC current driven through an inductor cable. Figure 3 shows generator in the surface that will flow the electric current using RF antenna to heat a reservoir. The inductor cable is placed in a circle in the reservoir, and reservoir heating using inductor cables is a new technology developed by Siemens, a joint project with Winter shall (Rafiee et al., 2015; Taheri-Shakib et al., 2018b). EM heating emphasizes the joule effect of eddy currents using AC current, the conduction path in eddy current is connate water in the reservoir. The electric current is converted to heat through this pathway due to the electrical resistivity in the water formation containing dissolved salt ions. The form of electrical permittivity and conductivity along with the frequency used could determine current distributions which depend on the characteristic of the electrical medium (Chen et al., 2018; Rafiee et al., 2015; Roland et al., 2011; Sadeghi et al., 2017b). The advantages of the EM method are that the transfer of thermal energy to the reservoir is very effective and could be controlled directly, where it is not limited to depth, heterogeneous formations, low formation permeability, and lithology of the formation. Discontinuous power supply (windmills, solar energy) is feasible to use which the upper heating temperature limit with current technology approximately $250^{\circ} \mathrm{C}$, and a small environmental footprint is possible (Rafiee et al., 2015).

\section{Ultrasonic Waves}

One of the electrical heating methods for enhanced oil recovery is ultrasonic waves. Ultrasonic has frequencies above human hearing that is around $20 \mathrm{kHz}$. The role of ultrasonic waves is to move particles in the sample. The technical stimulation of ultrasonic waves is to support the EOR process and avoid any damage to the production formation 
including in the promising stimulation technology for new wells to improve oil recovery (Abdulfatah, 2018). Ultrasonic waves will create vibrations around the reservoir by increasing capillary strength, adhesion between rocks, and liquids which they will facilitate the production and cause of oil coalescence. The ultrasonic wave has been tested in the Samathor oil field, Western Siberia. The ultrasonic wave technology increased oil recovery around 30-50\% with the permeability higher than $20 \mathrm{MD}$ and the porosity higher than 15\% (Abramov et al., 2013).

\section{Radio Frequency}

Radio Frequency (RF) technology is often applied for the cumulative acquisition of heavy oil around the borehole (Bientinesi et al., 2013; Bogdanov et al., 2014). Radiofrequency heating is a cheaper and faster method which has uniform heating for the entire area and could even be applied to deeper formations than ERH. Literature shows that radiofrequency $(\mathrm{RF})$ is more practical than electric resistivity heating $(\mathrm{ERH})$, with oil recovery ranging from 50 to 80\% (Ramcharan \& Hosein, 2019), when the RF process occurs continuously and provides excessive heat around the borehole, it could damage the integration around the borehole and equipment from the radio frequency ( $\mathrm{Z}$. Wang et al., 2018).

Electromagnetic radiation of radiofrequency driven from the antenna located in the wellbore near to reservoir layer containing heavy oil (Bera \& Babadagli, 2017; Davletbaev et al., 2010; Saeedfar et al., 2016). A considerable distance into the previous oil-carrying layers will be penetrated by electromagnetic energy in which electromagnetic will be either absorbed or removed and converted into thermal energy that is about $5 \mathrm{~kW}$ or even the highest of $100 \mathrm{~kW}$ (Oloumi \& Rambabu, 2016). Frequency equipment consists of an antenna array for heavy oil-heating. The calculation between electromagnetic fields and temperature could be able to coordinate reservoir properties and temperature distribution (Bientinesi et al., 2013; Davletbaev et al., 2011).

Figure 4 shows the conceptual design of EM, the surface equipment such as electric source or generator. The electric current flows using cable into the reservoir that the subsurface equipment will convert the electric current into heat on the vertical well to reduce viscosity around the wellbore. This Radio-frequency method is also adequate for rapid heating and relatively small heat loss. This method will increase the efficiency of oil production and transmits heatdriven from heat conduction through the casing into the reservoir (Kasevich et al., 1997; Z. Wang et al., 2019). Particularly, radio frequency could reduce heat loss through the seal rock (Cerutti et al., 2013), however the disadvantage of this method is the relatively high deployment cost compared to the resistive and inductive electrical heating methods, and electrical heating has a limited range, especially when the capacities of heat transfer are not good enough to transfer (Oloumi \& Rambabu, 2016; Z. Wang et al., 2018).

Downhole antennas will emit the high electromagnetic required by the rate of electric heating that surrounds the antenna to produce a higher electromagnetic field (Marfissi et al., 2009). The process of electromagnetic heating to achieve a heating volume must consider the design of the antenna around the wellbore, and the energy distributions must take into consideration the process of electromagnetic heating. This prevents exposure to components of well completion at extreme temperatures when irradiated with high Electromagnetic power to the reservoir (Hascakir et al., 2010).

At this time, the RF method is combined with a downhole antenna using an interface structure. The combination of the downhole antenna with an interface structure (tight shell) at the figure above is realized by radiating well and reservoir. The schematic method in Figure 5 shows that the oil well illustrated in the right part, called the settlement schemed. RF/MW components are accommodated based on a design such as a Figure 5 that allows the electromagnetic radiations to be high power (high power sources on the surface units, downhole transmission lines, and downhole antennas) and tight shell (cylinder structures placed around the well and reservoir through drilling and finishing operations at the depth of an antenna installation) (Cerutti et al., 2013). Impermeable zone and low loss dielectric must be considered to create a tight shell in which electrical heating is divided into two parameters, low frequency for ohmic and resistive heating for microwave heating method.

\section{a. Low frequency electric resistive /ohmic}

Low-frequency electric, called ohmic or joule heating, is a method to heat the reservoir by flowing electrical current through the formation (Martin et al., 2017; Rehman \& Meribout, 2012; Seidi Damyeh et al., 2016). Figure 6 shows that Low frequency converts electrical heating to heat energy when ohmic occurs from AC current flowing to the reservoir (Sahni et al., 2000). The aim of the low-frequency electric implementation inside the reservoir is to provide a heating source and facilitate the oil flow to reduce oil viscosity induced by locally increased temperature.

Potential different from the picture above, which the electrodes could help the oil flowing due to the current, could be applied to the reservoir with salt contents and distribute heat. The various types of the reservoir could apply the low-frequency for electrical heating which the formation has heterogeneous porosity, permeability, variable depth or thickness, even though the temperature and pressure which have various value for each side (Rehman \& Meribout, 2012). Low frequency has been tested in several field such as in the Rio Panon Field in Brazil, which it successfully 
increased oil recovery using low-frequency AC $(300 \mathrm{~Hz})$. The electrical heating method was applied because the characteristics are appropriate for the application of the thermal method (Pizarro \& Trevisan, 1990).

\section{b. High frequency (Microwave heating)}

Microwave heating has high-frequency heating where the wave ranges from $300-300000 \mathrm{MHz}$ (Hanyong et al., 2018). It is called a microwave because of a short wavelength in which microwave produces more efficient heat at the adsorption in the material but crude oil does not have good adsorption in the microwave. Therefore, the design and dielectric properties affect microwave heating (H. Wang et al., 2017; J. Zhu et al., 2019). The dielectric properties depend on the operating frequency, reservoir temperature, etc. Combination of hydrocarbon and sand could absorb large amounts of heat, and the microwave could rapidly heat them as well as temperature up to $300-400{ }^{\circ} \mathrm{C}$ (Rehman \& Meribout, 2012; Taheri-Shakib et al., 2017a). The applications of microwave heating have been applied in the Suncor oil field, Alberta, which resulted in the production of synthetic crude whose composition was similar to the real crude oil (Ali \& Bayestehparvin, 2018).

Microwave is transmitted through a unit called a waveguide, located on the surface. Waves that move from the waveguide will be emitted from the subsurface antenna to the source of the well (Bjorndalen \& Islam, 2004; Dandjouma et al., 2006; Nasri \& Mozafari, 2018; Taheri-Shakib et al., 2018a). The antenna is placed at the waterhydrocarbon interface, and the source well is surrounded by production wells (Demiral et al., 2008; Taheri-Shakib et al., 2017b). Liquid and steam products are simultaneously pumped from sources and production wells, which fluid from the production well is transferred to the storage tank. Steam is condensed into liquid and stored separately, and uncondensed steam will be released, burned, or re-treatment, depending on the project location. The fluid pump obtains hydrocarbons from the top of the water face and produces little water. The energy source effectively pulls the hydrocarbon wadding toward the production well. The microwave system only recovers free products and volatile steam. Laboratory experiments also show that microwave energy will magnify MTBE, it could be seen in Figure 7 (Ferri \& Uthe, 2001).

Microwave studies have shown that when a microwave is added a chemical reaction, increasing the temperature up to 10-1000 times faster than conventional heating. Recently, petroleum industries have been applying the microwave heating for bitumen and heavy oil. One of the advantages of the microwave study could be reducing viscosity (more than $96 \%$ ) and the reaction time is shorter (less than 60 minutes) which the temperature tends to $150{ }^{\circ} \mathrm{C}$ (Mozafari \& Nasri, 2017).

Microwave technology has been proven to reduce costs, compared to alternative methods such as pumps and maintenance systems by eliminating contamination in source wells without further maintenance (Ferri \& Uthe, 2001). There are two processes of microwave heating that the electrical energy will be input and converted into the microwave before converted into the effective heat. Short processing time of rapid heating and precise control processes become the advantage of microwave irradiation that results in energy efficiency as an economic performance index which approximately $80 \%$ of total energy could be reached (Mozafari \& Nasri, 2017).

\section{DISCUSSION}

Since the reduction in light oil reserves, heavy oil has been produced commercially. Heavy oil and bitumen reserves are approximately 8-9 trillion barrels or 53\% of total recoverable oil shown in Figure 8, and most of them come from conventional oil deposited in deep formation which migrates to areas affected by bacteria and weathering (J. G. Speight, 2013).

Therefore, a conventional method could not be applied in low API $(<20)$ reservoir as seen in Table 2 showing the crude oil classifications (Hill, 2014). Technology of heavy oil production has been developed in many years and has been a task of high importance and complexity which integrated studies approach planning and piloting is a success key of heavy oil projects (Rana et al., 2007).

One of the electrical heating developments is to use mineral isolated in which electrical heating using mineral isolated is to purpose start-up period from heat source, it could be self-regulating to manage reservoir temperature and to avoid an overheating reservoir. This method does not need brine to conduct electricity that polymer and graphite are used instead of brine. Not only electrical heating increases the temperature, but the mineral resistance also increases temperature even more (Rehman \& Meribout, 2012). This method could efficiently avoid a steam breakthrough and be cost less than other conventional methods for heavy oil recovery. In this case, formation damage could be neglected because there is no fluid injected into the reservoir (Rangel-German et al., 2004).

Meanwhile, another method for the prospect of electrical heating is the electrothermal complex that has been applied for Russia's oil field (Usinskoe oil field dan Gremihinskoe) which they were applying conventional thermal injection. The electrothermal complex is an advanced steam injection technology applied for heavy oil recovery that can improve oil recovery than any thermal method. The electrical heating device and downhole heating generator are the objectivities of the electrothermal complex that will replace the conventional method injecting steam from the 
generator through heat-insulted tube strings into the well, which the disadvantage of this method is high capital cost. The electrical heating device is purposed for well bottom zone heating, and the downhole steam generator could provide conventional steam flooding. This method could increase steam quality up to 0.8-1 than the traditional steam generator (0.4-0.5), and the advantages of this method are high steam quality, low capital cost, and ecological safety. The electrothermal complex consists of several important parts as seen in the Figure 9; (1) current regulator; (2) pump; (3)electrical drive; (4)working liquid; (5) power cable; (6)tubing; (7) oil-flooded; (8) dielectric insertion; (9) heat-resistant input lead; (10) packer; (11) downhole heating generator; (12) casing string; (13) oil-field water; (14)steam port. The electorthermal complex can also be combined with a miscible method, namely solvent injection to increase thermal efficiency.

Besides, the latest method that could be used to overcome problems in the development of electric heating is artificial intelligence. Artificial intelligence could solve some cases in many ways. AI refers to algorithms that could be taught to some works, and AI also plays roles in the oil and gas industries which could be used as a predictive or smart, selfcalibrating sensors monitoring operation equipment, and forecasting operational issues and potential failures (Kandziora, 2019). Artificial intelligence and machine learning are a method using the domain of computational intelligence. Based on data, artificial intelligence could model a learning system without being explicitly programmed to predict informations (Basfar et al., 2018). For example, in Electrical heating method, the interconnected nodes could be simulated using artificial neural network (ANN) based on individual neurons. This method draws the pattern recognitions and forecasting in some situations of the complex process (Olawoyin \& Chen, 2018). Artificial intelligence could be applied for electrical heating to predict heat quantities required by the reservoir, when electrification increases the number of controllable units as the energy system becomes more complex which simulation data could be input into using algorithms to be taught using machine learning before artificial intelligence is ready to use. ANN using the biological human system, Figure 10 gives information about the principle of the neural network, which the $X$ value is an output system multiplied by which the $W$ values correspond to the $X$ value. The output value $\mathrm{F}(\mathrm{x}, \mathrm{W})$ or result could be obtained using data in hidden layers (results of multiplication $\mathrm{Xn}$ and $\mathrm{Wn}$ ) (Ibrahim et al., 2017).

Trautman et al. (2012) reported a new method of electromagnetic using solvent extraction, called Enhanced Solvent Extraction Incorporating Electromagnetic Heating Technology (ESEIEH), which has been patented and is currently undergoing pilot projects. This project has been developed in Alberta, Couldada. ESEIEH is a heating method using solvents such as propane and butane applied in the Couldadian-oil sands that is commonly designed for horizontal well, which radiofrequency and electromagnetic waves are a combination to result in heat. Laricina, Nexen, and Suncor develop ESEISEH projects using an antenna in the reservoir that emits to raise the temperature up to $50^{\circ} \mathrm{C}$ $(120 \mathrm{oF})$ (Abraham et al., 2016; Hassanzadeh et al., 2017). Faradonbeh et al. (2016) purposed a method of electrical heating using solvent and water as a fluid transfer to target heat into the formation for in-situ extraction of bitumen using downhole electrical heating. Then it will create the vapor chamber that could be used before the SAGD project takes place, and it is highly promising to reduce the water surface to create steam (Andarcia et al., 2014; Guo et al., 2019; Ramcharan \& Hosein, 2019). Therefore, it more advantages over the conventional SAGD project in the side of capital operation cost (Seeam et al., 2018). Figure 11 shows the experimental of ESEIEH using the microwave in which the syringe pump injects the solvent. Because diffusion and gravity force could mix the solvent with heavy oil, however, water wet of heavy oil must be created before injecting solvent, then the recovered oil will be flowing down into a baker glass. Electrical heating was carried out for advanced development to produce heavy oil.

Finally, the development of electrical heating is nanoparticles which have been widely studied for various fields to obtain the heat exchange performances by increasing the surface wettability of solid because more atoms are involved in the heat transfer when the surface-fluid interaction is increased. They occur to catalyze the breaking of carbonsulfur bonds within asphaltic components in the increased saturates and aromatics. Therefore, it will be lowering the oil viscosity and constantly reducing the molecular weight (Greff \& Babadagli, 2013). Chandra et al. (2019) has mathematically studied for nano-particles assisted electromagnetic heating using nano-sized Fe2O3 (hematite) prepared on brine as a colloidal system with the optimum concentration to reduce oil viscosity and mobility ratio, in which Fe2O3 acted as conductive heat intermediary. Ferizal et al. (2013) also suggest the application of Fe2O3 in electromagnetic heating process in the gravel-sand pack to prevent the sand production as well as increasing the production of heavy-oil well.

Figure 12 demonstrates the temperature and pressure profile for a month heating by assuming the steady state during heat transfer, in which the reservoir temperature is about 1,100 psi with a drainage radius of $25 \mathrm{~m}$. However, the well has been shut-in because of the favorable economic situation, caused by excessive pump power required to produce heavy oil. According to the calculated numerical scheme, the nanoparticles-assisted electromagnetic heating does not seem promising that the process after a month only reached $5 \mathrm{~m}$ of drainage radius, it requires further calculations regarding the increased flow rate because of viscosity reduction. According to the calculated numerical scheme, the nanoparticles-assisted electromagnetic heating does not seem promising that the process after a month only reached $5 \mathrm{~m}$ of drainage radius, it requires further calculations regarding the increased flow rate because of viscosity reduction. 
This method can be encouraging for viscosity reduction only, and to optimize the production recovery must consider other mechanisms such as pressure using waterflooding or cyclic shut-in method.

Using an electric current to generate heat and increase the temperature around the wellbore was designed for the combustion method. However, it has been developed over the world to reduce oil viscosity because of flow rate incremental thereby increasing oil recovery (J. Speight, 2016). Downhole heating has begun to be conducted trials in Papua-Indonesia, the Klamono field located offshore of the saltwater basin, in which the kimono field is a shallow reservoir with high oil viscosity. The field is conducting an electric downhole heater (EDH) to improve oil recovery that will be installed in conjunction with a tubing joint to facilitate its application in the well. The results obtained in the application of $\mathrm{EDH}$ is that there is a reduction in the density of $0.01 \mathrm{cP}$ per $\Delta \mathrm{T}=9^{\circ} \mathrm{C}$ following the objectives of the thermal method. Viscosity reduction can increase oil mobility through water mobility and can reduce WC from $97.5 \%$ to $96.9 \%$. Based on the real data tested, the field yields a profit margin of $40.5 \mathrm{USD} / \mathrm{bopd}$ before EDH installed and 41.9 USD/bopd after installation, which it successfully increased around 1.4 USD/bopd. NO-EDH installation field yields 6.1 million USD and the EDH installation field produces 9.7 million USD which, after subtracted by the rig rent, would be 6.3 million USD. Therefore, the additional 0.2 million USD of profit margin is economically viable (Hakiki et al., 2017). Utilization of renewable energy is a solution in the development of future energy, both from organic or inorganic waste to reduce gas emission as the government regulations for future energy (Afdhol, Abdurrahman, et al., 2019; Afdhol, Lubis, et al., 2019; Yuliusman et al., 2018). The laboratory experiments and numerical models have been developed in various studies to improve electrical heating for heavy oil as well as eco-friendly and economical terms. Smart and sustainable district heating holds great potential to meet energy efficiencies by reducing emissions, which producing heating from electricity using the sludge from waste material as a component producing electricity from biogas or raw material could be solutions for long terms to reach sustainable energy to produce electricity in eco-friendly ways (Afdhol et al., 2020; Chhetri \& Islam, 2008; Yuliusman et al., 2017). Thus, numerous studies had been done to discover new, inexpensive, and renewable raw materials (Abechi et al., 2013; Derman et al., 2018; Rocha-Meneses et al., 2019).

\section{CONCLUSION}

Electrical-enhanced oil recovery (EEOR) is one of EOR methods that could be an alternative method for heavy oil than the conventional method. There are three fundamental heat transfers of the electrical heating method into the formation using electric current (heat conduction, heat convection, and radiation heat transfer). The amount of required electric current depends on the production rate because when the hot water is producing, the colder fluid will be flowing from the reservoir to the well. The excessive energy will give uncontrolled temperature and damages formation where electric current and components affect performances of electrical heating. The past and current developments have been carried out to fill up the gap of electrical heating projects. The prospects must meet energy efficiency, and the excessive heat will damage formation that must be tackled in the future prospect. The works adopt several electrical heating projects and applications over the world where the work gives a brief future project of electrical heating.

\section{Acknowledgements}

The authors appreciate the support from Universitas Islam Riau for providing the access of all literature.

\section{Abbreviations}

The following abbreviations are used for this manuscript:

$\mathrm{AC}$

AI

ANN

API

CSS

DC

EEOR

\section{EM}

EOR

ERH

ESEIEH
Alternative current

Artificial intelligence

Artificial neural network

Americould petroleum institute

Cyclic stem stimulation

Direct current

Electrical enhanced oil recovery

Electromagnetic

Enhanced oil recovery

Electrical resistive heating

Enhanced solvent extraction incoperating electromagnetic heating technology 
GEHGD Gas and electrical heating gravity drainage

MMT Million metric ton

MW Mircrowave

OOIP Original oil in place

KW Kilowatt

RF Radio frequency

RF-EM Radio frequency-electromagnetic

RFH Radio frequency heating

\section{References}

Abdulfatah, H. K. (2018). Application of Ultrasonic Waves in Enhancing Oil Recovery in Secondary Recovery Phase. SPE Annual Technical Conference and Exhibition.

Abdurrahman, M., Ferizal, F. H., Husna, U. Z., \& Pangaribuan, L. (2018). Possibility of wax control techniques in Indonesian oil fields. AIP Conference Proceedings, 1941. https://doi.org/10.1063/1.5028059

Abechi, S. E., Gimba, C. E., Uzairu, A., \& Dallatu, Y. A. (2013). Preparation and characterization of activated carbon from palm kernel shell by chemical activation. Research Journal of Chemical Sciences, 3(7), 54-61.

Abraham, T., Afacan, A., \& Thundat, T. (2016). Electrical Heating Strategies for Oil Sands Based on Their Dynamic Electrical Behavior. World Heavy Oil Congress.

Abramov, V. O., Mullakaev, M. S., Abramova, A. V, Esipov, I. B., \& Mason, T. J. (2013). Ultrasonic technology for enhanced oil recovery from failing oil wells and the equipment for its implemention. Ultrasonics Sonochemistry, 20(5), 1289-1295.

Ado, M. R., Greaves, M., \& Rigby, S. P. (2018). Effect of pre-ignition heating cycle method, air injection flux, and reservoir viscosity on the THAI heavy oil recovery process. Journal of Petroleum Science and Engineering; $166,94-103$

Afdhol, M. K., Abdurrahman, M., Hidayat, F., Chong, F. K., \& Mohd Zaid, H. F. (2019). Review of Solvents Based on Biomass for Mitigation of Wax Paraffin in Indonesian Oilfield. Applied Sciences, 9(24), 5499. https://doi.org/10.3390/app9245499

Afdhol, M. K., Hidayat, F., Abdurrahman, M., Husna, U. Z., Sari, N. P., \& Wijaya, R. K. (2020). A Laboratory Scale Synthesis of Ethanol from Agricultural Waste as Bio-based Solvent for Waxy-Paraffinic Crude Oil Mitigation. IOP Conference Series: Materials Science and Engineering, 854(1), 012017. https://doi.org/10.1088/1757-899X/854/1/012017

Afdhol, M. K., Lubis, H. Z., \& Siregar, C. P. (2019). Bioethanol Production from Tea Waste as a Basic Ingredient in Renewable Energy Sources. Journal of Earth Energy Engineering, 8(1), 21. https://doi.org/10.25299/jeee.2019.vol8(1).2602

Ali, S. M. (1982). Steam Injection Theories-A Unified Approach. SPE California Regional Meeting.

Ali, S. M., \& Bayestehparvin, B. (2018). Electrical Heating-Doing the Same Thing Over and Over Again.... SPE Canada Heavy Oil Technical Conference.

Alvarado, V., \& Manrique, E. (2010). Enhanced oil recovery: an update review. Energies, 3(9), 1529-1575.

Andarcia, L., Bermudez, J. M., Reyes, Y., Caycedo, H., \& Suarez, A. F. (2014). Potential of Steam Solvent Hybrid Processes in Llanos Basin, Colombia. In SPE Heavy and Extra Heavy Oil Conference: Latin America (p. 16). Society of Petroleum Engineers. https://doi.org/10.2118/171049-MS

Bao, Y., Wang, J., \& Gates, I. D. (2017). Steam injection gravity drainage as a follow-up process for cyclic steam stimulation. Journal of Petroleum Science and Engineering, 153, 268-282. https://doi.org/https://doi.org/10.1016/j.petrol.2017.04.002

Basfar, S., Baarimah, S. O., Elkatany, S., AL-Ameri, W., Zidan, K., \& AL-dogail, A. (2018). Using Artificial Intelligence to Predict IPR for Vertical Oil Well in Solution Gas Derive Reservoirs: A New Approach. SPE Kingdom of Saudi Arabia Annual Technical Symposium and Exhibition.

Batycky, J. P., Leaute, R. P., \& Dawe, B. A. (1997). A Mechanistic Model of Cyclic Steam Stimulation. In 
International Thermal Operations and Heavy Oil Symposium (p. 14). Society of Petroleum Engineers. https://doi.org/10.2118/37550-MS

Bera, A., \& Babadagli, T. (2015). Status of electromagnetic heating for enhanced heavy oil/bitumen recovery and future prospects: A review. Applied Energy, 151, 206-226. https://doi.org/10.1016/j.apenergy.2015.04.031

Bera, A., \& Babadagli, T. (2017). Effect of native and injected nano-particles on the efficiency of heavy oil recovery by radio frequency electromagnetic heating. Journal of Petroleum Science and Engineering, 153, 244-256. https://doi.org/10.1016/j.petrol.2017.03.051

Bientinesi, M., Petarca, L., Cerutti, A., Bandinelli, M., Simoni, M. De, Manotti, M., \& Maddinelli, G. (2013). Journal of Petroleum Science and Engineering A radiofrequency / microwave heating method for thermal heavy oil recovery based on a novel tight-shell conceptual design. Journal of Petroleum Science and Engineering, 1-13. https://doi.org/10.1016/j.petrol.2013.02.014

Bjorndalen, N., \& Islam, M. R. (2004). The effect of microwave and ultrasonic irradiation on crude oil during production with a horizontal well. Journal of Petroleum Science and Engineering, 43(3-4), 139-150.

Bogdanov, I., Cambon, S., \& Prinet, C. (2014). Analysis of Heavy Oil Production by Radio-Frequency Heating. In SPE International Heavy Oil Conference and Exhibition (p. 13). Society of Petroleum Engineers. https://doi.org/10.2118/172862-MS

Carlson, M. (2003). SAGD and Geomechanics. Journal of Canadian Petroleum Technology, 42(06).

Cerutti, A., Bandinelli, M., Bientinesi, M., Petarca, L., Simoni, M., Manotti, M., \& Maddinelli, G. (2013). A New Technique for Heavy Oil Recovery Based on Electromagnetic Heating: System Design and Numerical Modelling. Chemical Engineering Transactions, 32, 1255. https://doi.org/10.3303/CET1332210

Chandra, S., Winarto, H., \& Rachmat, S. (2019). Mathematical model to predict unsteady-state heat transfer mechanism and economic feasibility in nanoparticle-assisted electromagnetic heating stimulation technique for bituminous extra-heavy oil reservoir. Journal of Petroleum Exploration and Production Technology, 9(2), $1255-1261$.

Chen, J.-H., Georgi, D. T., \& Liu, H.-H. (2018). Electromagnetic thermal stimulation of shale reservoirs for petroleum production. Journal of Natural Gas Science and Engineering, 59, 183-192.

Chhetri, A. B., \& Islam, M. R. (2008). A critical review of electromagnetic heating for enhanced oil recovery. Petroleum Science and Technology, 26(14), 1619-1631.

Dandjouma, A. K. A., Tchiégang, C., Kapseu, C., Fanni, J., \& Parmentier, M. (2006). Changes in Canarium schweinfurthii Engl. oil quality during microwave heating. European Journal of Lipid Science and Technology, 108(5), 429-433.

Das, S. K. (2007). Application of thermal processes in heavy oil carbonate reservoirs. In SPE Middle East Oil and Gas Show and Conference (p. 9). Society of Petroleum Engineers. https://doi.org/10.2118/105392-MS

Das, S. K. (2008). Electro magnetic heating in viscous oil reservoir. International Thermal Operations and Heavy Oil Symposium.

Davison, R. J. (1995). Electromagnetic stimulation of Lloydminster heavy oil reservoirs: field test results. Journal of Canadian Petroleum Technology, 34(04).

Davletbaev, A., Kovaleva, L., \& Babadagli, T. (2011). Mathematical modeling and field application of heavy oil recovery by radio-frequency electromagnetic stimulation. Journal of Petroleum Science and Engineering, $78(3-4), 646-653$.

Davletbaev, A., Kovaleva, L., Babadagli, T., \& Minnigalimov, R. (2010). Heavy oil and bitumen recovery using radiofrequency electromagnetic irradiation and electrical heating: Theoretical analysis and field scale observations. Canadian Unconventional Resources and International Petroleum Conference.

Demiral, B., Akin, S., Acar, C., \& Hascakir, B. (2008). Microwave Assisted Gravity Drainage of Heavy Oils. In International Petroleum Technology Conference (p. 9). International Petroleum Technology Conference. https://doi.org/10.2523/IPTC-12536-MS

Derman, E., Abdulla, R., Marbawi, H., \& Sabullah, M. K. (2018). Oil palm empty fruit bunches as a promising feedstock for bioethanol production in Malaysia. Renewable Energy, 129, 285-298. https://doi.org/10.1016/j.renene.2018.06.003

Dietz, D. N. (1975). Review of thermal recovery methods. Fall Meeting of the Society of Petroleum Engineers of 
AIME.

Doraiah, A., Ray, S., \& Gupta, P. (2007). In-situ combustion technique to enhance heavy oil recovery at Mehsana. ONGC-a Success Story SPE, 105248.

Faradonbeh, M. R., Hassanzadeh, H., \& Harding, T. (2016). Numerical simulations of bitumen recovery using solvent and water assisted electrical heating. Fuel, 186, 68-81.

Ferizal, F. H., Netzhanova, A. A., Lee, J., Bae, W., Suranto, A. M., \& Gunadi, T. A. (2013, June 11). Revitalizing Indonesia's Potential for Oil Production: The Study of Electromagnetically Heated Gravel Packs for Steamproduced Heavy Oil Reservoirs. SPE Heavy Oil Conference-Canada. https://doi.org/10.2118/165508-MS

Ferri, R. P., \& Uthe, M. T. (2001). Hydrocarbon remediation using microwaves. SPE/EPA/DOE Exploration and Production Environmental Conference.

Gates, I. D., \& Larter, S. R. (2014). Energy efficiency and emissions intensity of SAGD. Fuel, 115, 706-713.

Ghoodjani, E., Kharrat, R., Vossoughi, M., \& Bolouri, S. H. (2012). A review on thermal enhanced heavy oil recovery from fractured carbonate reservoirs. SPE Heavy Oil Conference Canada.

Giacchetta, G., Leporini, M., \& Marchetti, B. (2015). Economic and environmental analysis of a Steam Assisted Gravity Drainage (SAGD) facility for oil recovery from Canadian oil sands. Applied Energy, 142, 1-9.

Greff, J., \& Babadagli, T. (2013). Use of nano-metal particles as catalyst under electromagnetic heating for in-situ heavy oil recovery. Journal of Petroleum Science and Engineering, 112, 258-265. https://doi.org/10.1016/j.petrol.2013.11.012

Guo, W., Wang, Z., Sun, Z., Sun, Y., Lü, X., Deng, S., Qu, L., Yuan, W., \& Li, Q. (2019). Experimental investigation on performance of downhole electric heaters with continuous helical baffles used in oil shale in-situ pyrolysis. Applied Thermal Engineering, 147, 1024-1035.

Hakiki, F., Aditya, A., Ulitha, D. T., Shidqi, M., Adi, W. S., Wibowo, K. H., \& Barus, M. (2017, October 17). Well and Inflow Performance Relationship for Heavy Oil Reservoir under Heating Treatment. SPE/IATMI Asia Pacific Oil \& Gas Conference and Exhibition. https://doi.org/10.2118/186187-ms

Hanyong, L., Kexin, C., Ling, J., Leilei, W., \& Bo, Y. (2018). Experimental study on the viscosity reduction of heavy oil with nano-catalyst by microwave heating under low reaction temperature. Journal of Petroleum Science and Engineering, 170, 374-382.

Hascakir, B., Babadagli, T., \& Akin, S. (2008). Experimental and Numerical Modeling of Heavy-Oil Recovery by Electrical Heating. 11, 3976-3985. https://doi.org/10.2118/117669-ms

Hascakir, B., Babadagli, T., \& Akin, S. (2010). Field-scale analysis of heavy-oil recovery by electrical heating. SPE Reservoir Evaluation \& Engineering, 13(1), PP-131.

Hassanzadeh, H., Harding, T. G., Moore, R. G., Mehta, S. A., \& Ursenbach, M. G. (2016). Gas generation during electrical heating of oil sands. Energy \& Fuels, 30(9), 7001-7013.

Hassanzadeh, H., Rabiei Faradonbeh, M., \& Harding, T. (2017). Numerical simulation of solvent and water assisted electrical heating of oil sands including aquathermolysis and thermal cracking reactions. AIChEJournal, 63(9), $4243-4258$.

Hidayat, F., \& Abdurrahman, M. (2018). A Prospective Method to Increase Oil Recovery in Waxy-Shallow Reservoir. IOP Conference Series: Materials Science and Engineering, 306(1). https://doi.org/10.1088/1757899X/306/1/012040

Hill, D. (2014). Application of Electrokinetics for Enhanced Oil Recovery. Electrokinetics for Petroleum and Environmental Engineers, 103-155.

Hu, L., Li, H. A., Babadagli, T., \& Ahmadloo, M. (2017). Experimental investigation of combined electromagnetic heating and solvent-assisted gravity drainage for heavy oil recovery. Journal of Petroleum Science and Engineering, 154, 589-601. https://doi.org/10.1016/j.petrol.2016.10.001

Ibrahim, H., Sebayang, A. H., Dharma, S., \& Silitonga, A. S. (2017). Prediksi kinerja mesin diesel dengan bahan bakar biodiesel-solar menggunakan artificial neural network. Jurnal Muara Sains, Teknologi, Kedokteran Dan Ilmu Kesehatan, 1(1), 48-58.

Isaacs, E. (2011). Advances in Extra Heavy Oil Development Technologies (Isaacs). 20th World Petroleum Congress.

Ji, D., Yang, S., Zhong, H., Dong, M., Chen, Z., \& Zhong, L. (2016). Re-Examination of Fingering in SAGD and 
ES-SAGD. SPE Canada Heavy Oil Technical Conference.

Kandziora, C. (2019). Applying Artificial Intelligence to Optimize Oil and Gas Production. Offshore Technology Conference.

Kasevich, R. S., Price, S. L., \& Albertson, A. (1997). Numerical Modeling of Radio Frequency Heating Process for Enhanced Oil Production. In SPE Western Regional Meeting (p. 5). Society of Petroleum Engineers. https://doi.org/10.2118/38311-MS

Koolman, M., Huber, N., Diehl, D., \& Wacker, B. (2008). Electromagnetic heating method to improve steam assisted gravity drainage. International Thermal Operations and Heavy Oil Symposium.

Kusumastuti, I., Erfando, T., \& Hidayat, F. (2019). Effects of Various Steam Flooding Injection Patterns and Steam Quality to Recovery Factor. Journal of Earth Energy Engineering, 8(1), 33-39. https://doi.org/10.25299/jeee.2019.vol8(1).2909

Madhavan, R. M., \& Mamora, D. D. (2010). Experimental investigation of caustic steam injection for heavy oils. SPE Improved Oil Recovery Symposium.

Marfissi, S., Campos, F., Osuna, C., \& Brown, J. (2009). EVALUATION OF DOWNHOLE ELECTRICAL HEATING IN HEAVY OIL OF THE ORINOCO BELT, VENEZUELA.

Martin, E. J., Mumford, K. G., Kueper, B. H., \& Siemens, G. A. (2017). Gas formation in sand and clay during electrical resistance heating. International Journal of Heat and Mass Transfer, 110, 855-862.

McGee, B C W, Vermeulen, F. E., \& Yu, C. L. (1996). Electrical Heating With Horizontal And Vertical Wells. Annual Technical Meeting.

McGee, B C W, Vermeulen, F. E., \& Yu, L. (1999). Field test of electrical heating with horizontal and vertical wells. Journal of Canadian Petroleum Technology, 38(03).

McGee, Bruce C W, \& Vermeulen, F. E. (2007). The mechanisms of electrical heating for the recovery of bitumen from oil sands. Journal of Canadian Petroleum Technology, 46(01).

Melcon, S. (1965). Oil recovery by in situ combustion. Google Patents.

Melysa, R. (2016). Prediksi Kinerja Steamflood Dengan Metode Myhill-Stegemeier dan Gomaa di Area R Duri Steamflood (DSF). Journal of Earth Energy Engineering, 5(2), 44-56. https://doi.org/10.22549/jeee.v5i2.478

Mozafari, M., \& Nasri, Z. (2017). Operational conditions effects on Iranian heavy oil upgrading using microwave irradiation. Journal of Petroleum Science and Engineering, 151, 40-48. https://doi.org/https://doi.org/10.1016/j.petrol.2017.01.028

Nasr, T N, Law, D. H. S., Golbeck, H., \& Korpany, G. (2000). Counter-current Aspect of the SAGD Process. Journal of Canadian Petroleum Technology, 39(01), 7. https://doi.org/10.2118/00-01-03

Nasr, Tawfik Noaman, \& Ayodele, O. R. (2005). Thermal techniques for the recovery of heavy oil and bitumen. SPE International Improved Oil Recovery Conference in Asia Pacific.

Nasri, Z., \& Mozafari, M. (2018). Multivariable statistical analysis and optimization of Iranian heavy crude oil upgrading using microwave technology by response surface methodology (RSM). Journal of Petroleum Science and Engineering, 161, 427-444.

Olawoyin, A., \& Chen, Y. (2018). Predicting the Future with Artificial Neural Network. Procedia Computer Science, 140, 383-392.

Oloumi, D., \& Rambabu, K. (2016). Microwave heating of heavy oil reservoirs: A critical analysis. Microwave and Optical Technology Letters, 58(4), 809-813.

Onyekonwu, M. O., Pande, K., Ramey Jr, H. J., \& Brigham, W. E. (1986). Experimental and simulation studies of laboratory in-situ combustion recovery. SPE California Regional Meeting.

Pizarro, J. O. S., \& Trevisan, O. V. (1990). Electrical heating of oil reservoirs: numerical simulation and field test results. Journal of Petroleum Technology, 42(10), 1-320.

Putra, E. A. P., Rachman, Y. A., Arsyadanie, R., Hafizh, G., \& Firmanto, T. (2011). Case Study : Cyclic Steam Stimulation in Sihapas Formation. SPE Asia Pacific Oil and Gas Conference and Exhibition, 1-10. https://doi.org/SPE-147811

Rafiee, M., Behr, A., Lessner, E., Diehl, D., Trautmann, B., \& Koch, A. (2015). Electromagnetic heating for heavy oil production: Case study of a field applicability. Society of Petroleum Engineers - SPE Russian Petroleum 


\section{Technology Conference. https://doi.org/10.2118/176538-ru}

Ramcharan, T., \& Hosein, R. (2019). Radio Frequency Heating combined with Solvent Extraction-A method for oil recovery from surface oil sands. Journal of Petroleum Science and Engineering, 179, 328-336.

Rana, M. S., Sámano, V., Ancheyta, J., \& Diaz, J. A. I. (2007). A review of recent advances on process technologies for upgrading of heavy oils and residua. Fuel, 86(9), 1216-1231.

Rangel-German, E. R., Schembre, J., Sandberg, C., \& Kovscek, A. R. (2004). Electrical-heating-assisted recovery for heavy oil. Journal of Petroleum Science and Engineering, 45(3-4), 213-231. https://doi.org/10.1016/j.petrol.2004.06.005

Rehman, M. M., \& Meribout, M. (2012). Conventional versus electrical enhanced oil recovery: a review. Journal of Petroleum Exploration and Production Technology, 2(4), 157-167. https://doi.org/10.1007/s 13202-012-0034$\mathrm{x}$

Rocha-Meneses, L., Raud, M., Orupõld, K., \& Kikas, T. (2019). Potential of bioethanol production waste for methane recovery. Energy, 133-139. https://doi.org/10.1016/j.energy.2019.02.073

Roland, U., Holzer, F., \& Kopinke, F. (2011). Combining different frequencies for electrical heating of saturated and unsaturated soil zones. Chemical Engineering \& Technology, 34(10), 1645-1651.

Sadeghi, A., Hassanzadeh, H., \& Harding, T. G. (2017a). A comparative study of oil sands preheating using electromagnetic waves, electrical heaters and steam circulation. International Journal of Heat and Mass Transfer, 111, 908-916. https://doi.org/10.1016/j.ijheatmasstransfer.2017.04.060

Sadeghi, A., Hassanzadeh, H., \& Harding, T. G. (2017b). Modeling of desiccated zone development during electromagnetic heating of oil sands. Journal of Petroleum Science and Engineering, 154, 163-171. https://doi.org/10.1016/j.petrol.2017.04.033

Saeedfar, A., Lawton, D., \& Osadetz, K. (2016). Directional RF Heating for Heavy Oil Recovery Using Antenna Array Beam-Forming. In SPE Canada Heavy Oil Technical Conference (p. 34). Society of Petroleum Engineers. https://doi.org/10.2118/180695-MS

Sahni, A., Kumar, M., \& Knapp, R. B. (2000, April 4). Electromagnetic Heating Methods for Heavy Oil Reservoirs. SPE/AAPG Western Regional Meeting: https://doi.org/10.2118/62550-MS

Sandberg, C., Thomas, K., \& Hale, A. (2014). Advances in electrical heating technology for heavy oil production. SPE Heavy Oil Conference-Canada.

Santos, R. G., Loh, W., Bannwart, A. C., \& Trevisan, O. V. (2014). An overview of heavy oil properties and its recovery and transportation methods. Brazilian Journal of Chemical Engineering, 31(3), 571-590.

Seeam, A., Laurenson, D., \& Usmani, A. (2018). Evaluating the potential of simulation assisted energy management systems: A case for electrical heating optimisation. Energy and Buildings, 174, 579-586.

Seidi Damyeh, M., Niakousari, M., Golmakani, M. T., \& Saharkhiz, M. J. (2016). Microwave and ohmic heating impact on the in situ hydrodistillation and selective extraction of Satureja macrosiphonia essential oil. Journal of Food Processing and Preservation, 40(4), 647-656.

Sood, A. (2016). Convective SAGD Process. SPE Canada Heavy Oil Technical Conference.

Speight, J. (2016). Introduction to Enhanced Recovery Methods For Heavy Oil and Tar Sands (2nd ed.). Gulf Professional Publishing.

Speight, J. G. (2013). Enhanced recovery methods for heavy oil and tar sands. In Enhanced Recovery Methods for Heavy Oil and Tar Sands. https://doi.org/10.1016/C2013-(0-15525-0

Stinson, D. L., Carpenter, H. C., \& Cegielski Jr, J. M. (1976). Power recovery from in-situ combustion exhaust gases. Journal of Petroleum Technology, 28(06), 645-650.

Taheri-Shakib, J., Shekarifard, A., \& Naderi, H. (2017a). The experimental investigation of effect of microwave and ultrasonic waves on the key characteristics of heavy crude oil. Journal of Analytical and Applied Pyrolysis, 128, 92-101.

Taheri-Shakib, J., Shekarifard, A., \& Naderi, H. (2017b). The experimental study of effect of microwave heating time on the heavy oil properties: Prospects for heavy oil upgrading. Journal of Analytical and Applied Pyrolysis, $128,176-186$.

Taheri-Shakib, J., Shekarifard, A., \& Naderi, H. (2018a). Experimental investigation of the asphaltene deposition in porous media: accounting for the microwave and ultrasonic effects. Journal of Petroleum Science and 
Engineering, 163, 453-462.

Taheri-Shakib, J., Shekarifard, A., \& Naderi, H. (2018b). Experimental investigation of comparing electromagnetic and conventional heating effects on the unconventional oil (heavy oil) properties: Based on heating time and upgrading. Fuel, 228, 243-253. https://doi.org/10.1016/j.fuel.2018.04.141

Thakur, G. C. (1997). Heavy Oil Reservoir Management. Latin American and Caribbean Petroleum Engineering Conference.

Trautman, M., Ehresman, D., Edmunds, N., Taylor, G., \& Cimolai, M. (2012). Effective solvent extraction system incorporating electromagnetic heating (Patent No. WO2012067613A1).

Vincent, K. D., MacKinnon, C. J., \& Palmgren, C. T. S. (2004). Developing SAGD Operating Strategy using a Coupled Wellbore Thermal Reservoir Simulator. In SPE International Thermal Operations and Heavy Oil Symposium and Western Regional Meeting (p. 8). Society of Petroleum Engineers. https://doi.org/10.2118/86970-MS

Vinsome, K., McGee, B. C. W., Vermeulen, F. E., \& Chute, F. S. (1994). Electrical heating. Journal of Canadian Petroleum Technology, 33(04).

Wang, H., Rezaee, R., Saeedi, A., \& Josh, M. (2017). Numerical modelling of microwave heating treatment for tight gas sand reservoirs. Journal of Petroleum Science and Engineering, 152, 495-504.

Wang, Y., Wang, X., Xing, Y., Xue, J., \& Wang, D. (2017). Three-dimensional numerical simulation of enhancing shale gas desorption by electrical heating with horizontal wells. Journal of Natural Gas Science and Engineering, 38, 94-106.

Wang, Z., Gao, D., Diao, B., Tan, L., Zhang, W., \& Liu, K. (2019). Comparative performance of electric heater vs. RF heating for heavy oil recovery. Applied Thermal Engineering, 160, 114105. https://doi.org/10.1016/j.applthermaleng.2019.114105

Wang, Z., Gao, D., \& Fang, J. (2018). Numerical simulation of RF heating heavy oil reservoir based on the coupling between electromagnetic and temperature field. Fuel, 220(January), 14-24. https://doi.org/10.1016/j.fuel.2018.02.012

Wehunt, C. D., Burke, N. E., Noonan, S. G., \& Bard, T. R. (2003). Technical challenges for offshore heavy oil field developments. Offshore Technology Conference.

Xi, C., Qi, Z., Jiang, Y., Han, W., Shi, L., Li, X., Wang, H., Zhou, Y., Liu, T., \& Du, X. (2017). Dual-Horizontal Wells SAGD Start-Up Technology: From Conventional Steam Circulation to Rapid and Uniform Electric Heating Technology. In SPE Symposium: Production Enhancement and Cost Optimisation (p. 9). Society of Petroleum Engineers. https://doi.org/10.2118/189241-MS

Xiaoxiong, L. I. U., JIANG, Y., Yongbin, W. U., \& Jialu, W. (2018). A mathematical model and relevant index prediction for constant-temperature electric heating of dual-horizontal-well SAGD start-up. Petroleum Exploration and Development, 45(5), 895-902.

Yao, Z. X., Li, J. X., Wang, K., Song, Y. N., \& Li, X. (2019). Experimental and numerical study on direct electrical heating for plug removal of subsea waxy crude pipelines. International Journal of Heat and Mass Transfer, $143,118489$.

Yongbin, W., Xingmin, L., Wanjun, H., Fang, Z., Yueyue, F., Weinan, A., Youwei, J., \& Xiaoxiong, L. (2017). Numerical Simulation of Electrical-Heating Assisted SAGD in Heterogeneous Heavy Oil Reservoirs. SPE Reservoir Characterisation and Simulation Conference and Exhibition, 1-10. https://doi.org/10.2118/186023ms

Yuan, J. Y., Huang, H., Mintz, R., Wang, X., Jossy, C., \& Tunney, C. (2004). Wet electric heating for starting up SAGD/VAPEX. Canadian International Petroleum Conference.

Yuliusman, Afdhol, M. K., \& Sanal, A. (2018). Carbon monoxide and methane adsorption of crude oil refinery using activated carbon from palm shells as biosorbent. IOP Conference Series: Materials Science and Engineering, 316(1). https://doi.org/10.1088/1757-899X/316/1/012016

Yuliusman, Nasruddin, Afdhol, M. K., Amiliana, R. A., \& Hanafi, A. (2017). Preparation of Activated Carbon from Palm Shells Using KOH and $\mathrm{ZnCl} 2$ as the Activating Agent. IOP Conference Series: Earth and Environmental Science, 75(1). https://doi.org/10.1088/1755-1315/75/1/012009

Zhong, L., Yu, D., Yang, H., Sun, Y., Wang, G., \& Zheng, J. (2011). Feasibility Study on Produce Heavy Oil by Gas and Electrical Heating Assisted Gravity Drainage. Offshore Technology Conference. 
Zhu, J., Yang, Z., Li, X., Qi, S., Fang, Q., \& Ding, Y. (2019). The experimental study of microwave heating on the microstructure of oil shale samples. Energy Science \& Engineering, 7(3), 809-820.

Zhu, M., Zhong, H., Li, Y., Zeng, C., \& Gao, Y. (2015). Research on viscosity-reduction technology by electric heating and blending light oil in ultra-deep heavy oil wells. Journal of Petroleum Exploration and Production Technology, 5(3), 233-239.

Zhu, Z., Zeng, F., Zhao, G., \& Laforge, P. (2013). Evaluation of the hybrid process of electrical resistive heating and solvent injection through numerical simulations. Fuel, 105, 119-127.

Zyrin, V. O., \& Vasiliev, B. U. (2016). Electrothermal complex with downhole electrical heating generators for enhanced heavy oil recovery. International Journal of Applied Engineering Research, 11(3), 1859-1866. 


\section{Appendix}

Table 1. Pros and Cons of Electrical Heating Methods

\begin{tabular}{|c|c|c|c|}
\hline Method & Pros & Cons & Locations \\
\hline $\begin{array}{l}\text { Induction } \\
\text { Heating }\end{array}$ & $\begin{array}{l}\text { - able to be applied to the reservoir } \\
\text { which not suitable for thermal } \\
\text { methods }\end{array}$ & - the zone could be heated only near the wellbore & $\begin{array}{l}\text { - Frog Lake, North of Lloydminster, } \\
\text { Alberta, Canada (B C W McGee et al., } \\
\text { 1999). }\end{array}$ \\
\hline Low Frequency & $\begin{array}{l}\text { - able to be applied for the reservoir } \\
\text { with high-permeability and } \\
\text { fractures, based on energy supply } \\
\text { - a hot spot occurs near the end of } \\
\text { the electrode resulting limitations } \\
\text { of maximum power transfer and }\end{array}$ & $\begin{array}{l}\text { - temperature below a boiling point to maintain the } \\
\text { continuity } \\
\text { - in high salt concentration could result in corrosion } \\
\text { on the electrode }\end{array}$ & $\begin{array}{l}\text { - Lloydminster Heavy Oil Reservoirs } \\
\text { (Tests at Wildemere, Northminster and } \\
\text { Lashburn) (Davison, 1995). } \\
\text { - Rio Panon, Brazil (Pizarro \& Trevisan, } \\
\text { 1990). }\end{array}$ \\
\hline $\begin{array}{l}\text { Microwave } \\
\text { heating }\end{array}$ & 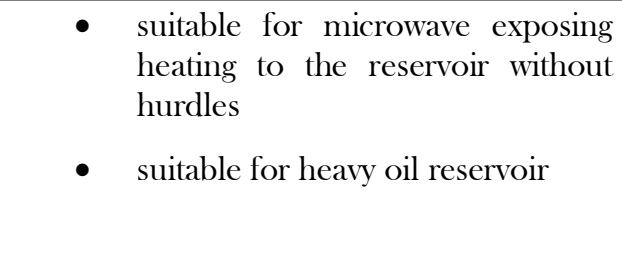 & $\begin{array}{l}\text { - } \text { production must be shut down } \\
\text { - has limitations of penetration depth in high } \\
\text { frequency } \\
\text { - not suitable for the reservoir with water flood } \\
\text { project }\end{array}$ & $\begin{array}{l}\text { - Suncor mine, Alberta } \quad \text { (Ali \& } \\
\text { Bayestehparvin, 2018). }\end{array}$ \\
\hline Ultrasonic & $\begin{array}{l}\text { - able to be applied for the reservoir } \\
\text { with High Sw and depleted } \\
\text { reservoir } \\
\text { - ableto be applied to lower oil } \\
\text { saturation }\end{array}$ & $\begin{array}{l}\text { - limited for vibration size due to the diameter of the } \\
\text { wellbore } \\
\text { - not suitable with a slurry mixture of sand and water } \\
\text { - not suitable to the compressive strength of } \\
\text { unconsolidated formation more than } 150 \mathrm{psi}\end{array}$ & $\begin{array}{ll}\text { - } & \text { Samathor oil field (Western Siberia) } \\
\text { (Abramov et al., 2013). }\end{array}$ \\
\hline
\end{tabular}


Table 2 Crude Oil Classifications (Santos et al., 2014)

\begin{tabular}{llll}
\hline Material & Gravity, ${ }^{\circ}$ API & $\mathbf{\rho}, \mathbf{k g} / \mathbf{m}^{\mathbf{3}}$ & $\boldsymbol{\mu}, \mathbf{c P}$ \\
\hline Bitumen & $<10$ & $\gg 1000$ & $\gg 10.000$ \\
Extra heavy & $<10$ & $>1000$ & $>10.000$ \\
Heavy oil & $10-22.3$ & $875-1000$ & $>100$ \\
Medium & $22.3-31.1$ & $825-875$ & $10-100$ \\
Light oil & $>31.1$ & $<875$ & $<10$ \\
\hline
\end{tabular}




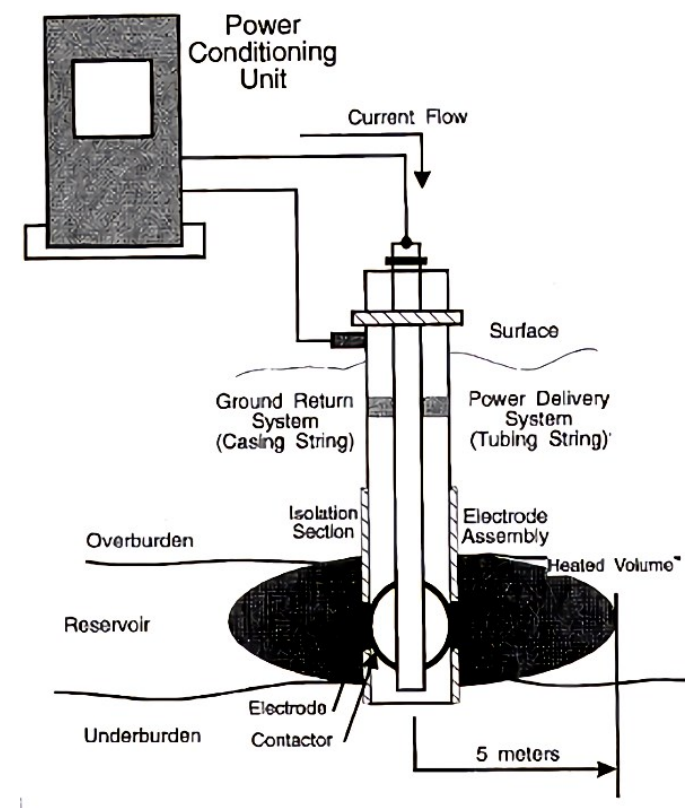

Figure 1 Electrical Heating Single Wellbore Configuration (B C W McGee et al., 1996)

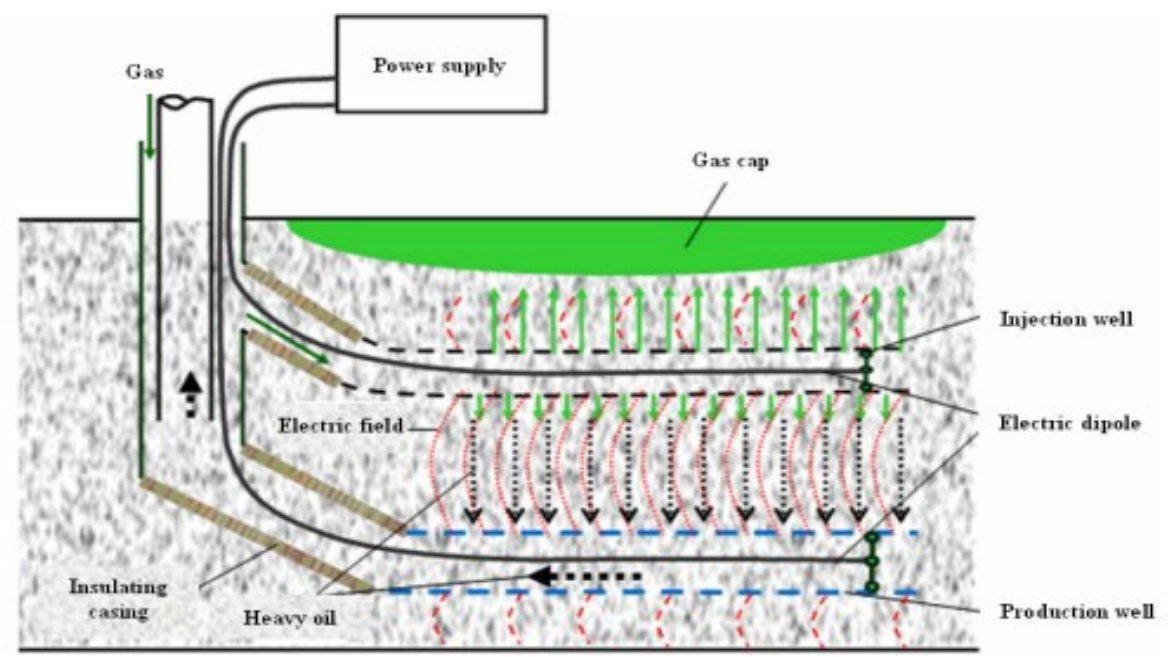

Figure 2 The Principle of GEGHD (Zhong et al., 2011) 


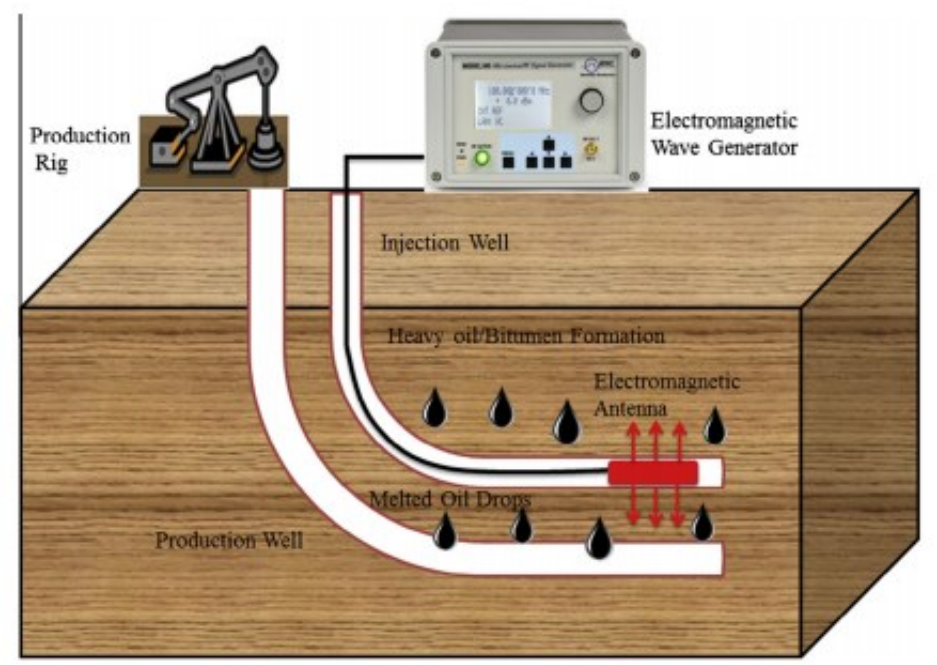

Figure 3 Electromagnetic Heating (Bera \& Babadagli, 2015)

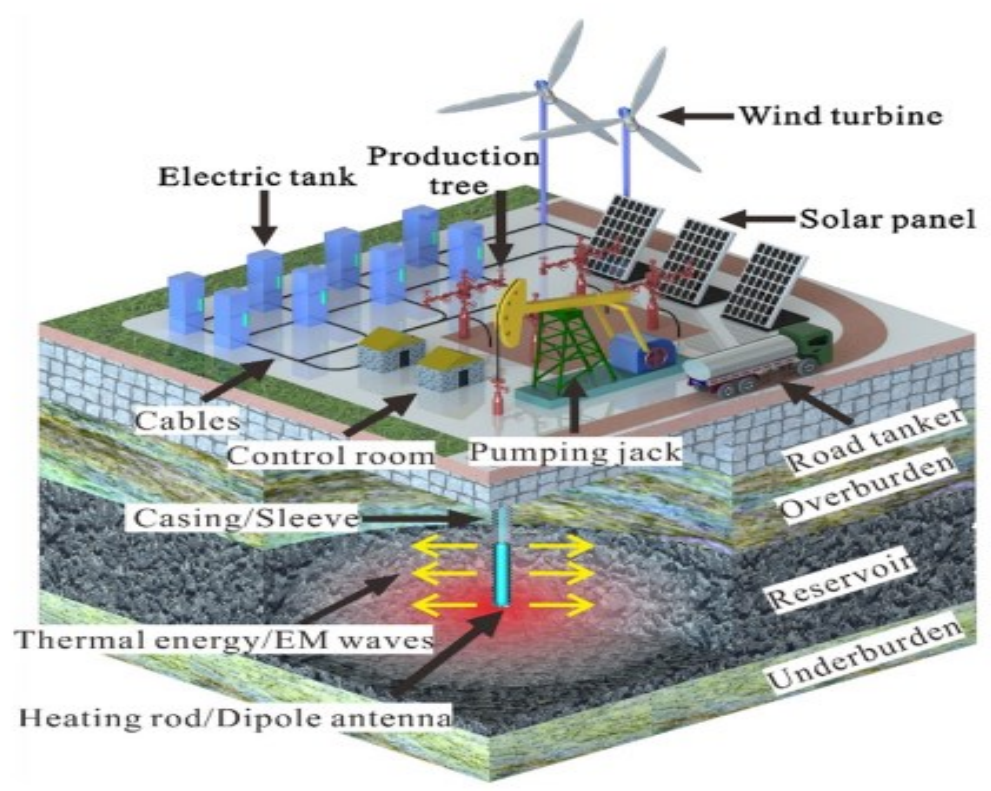

Figure 4 Design of Electromagnetic Heating (Z. Wang et al., 2019) 


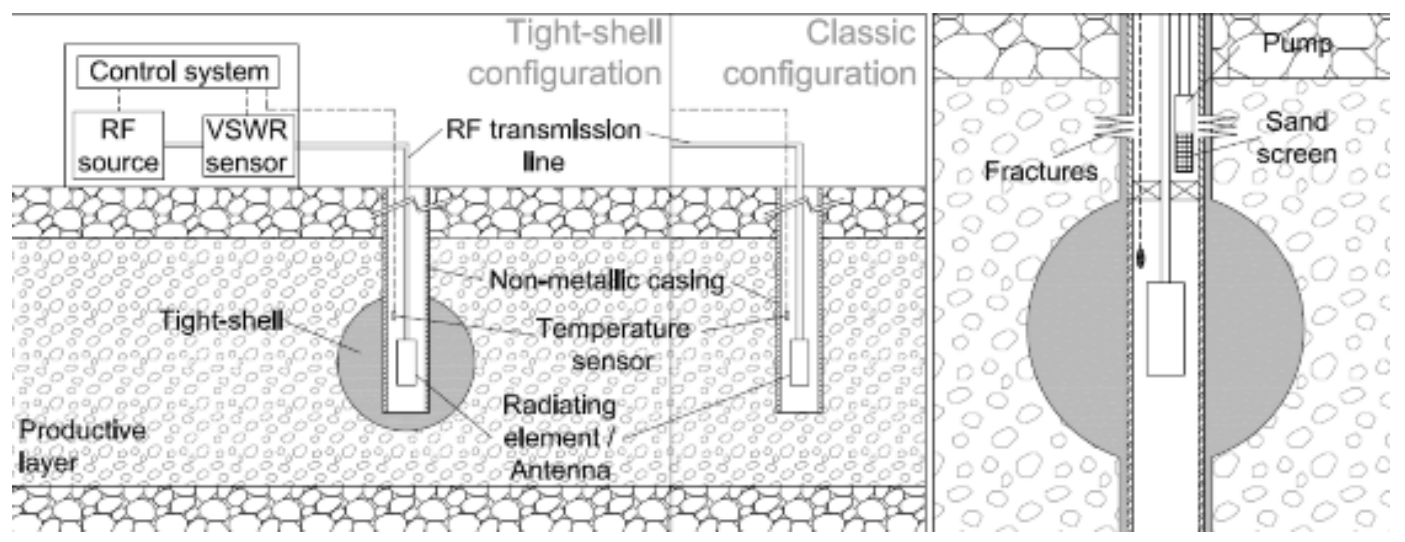

Figure 5 Radiation of Radio-Frequency in Tight-Shell (Left); Well Production Completion with Radio-Frequency (Right) (Cerutti et al., 2013)

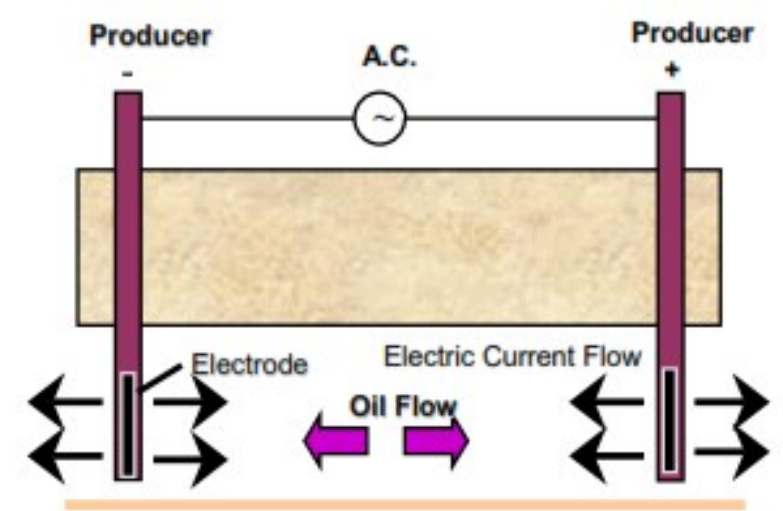

Figure 6 Schematic of Low Frequency Electric Resistive (Sahni et al., 2000)

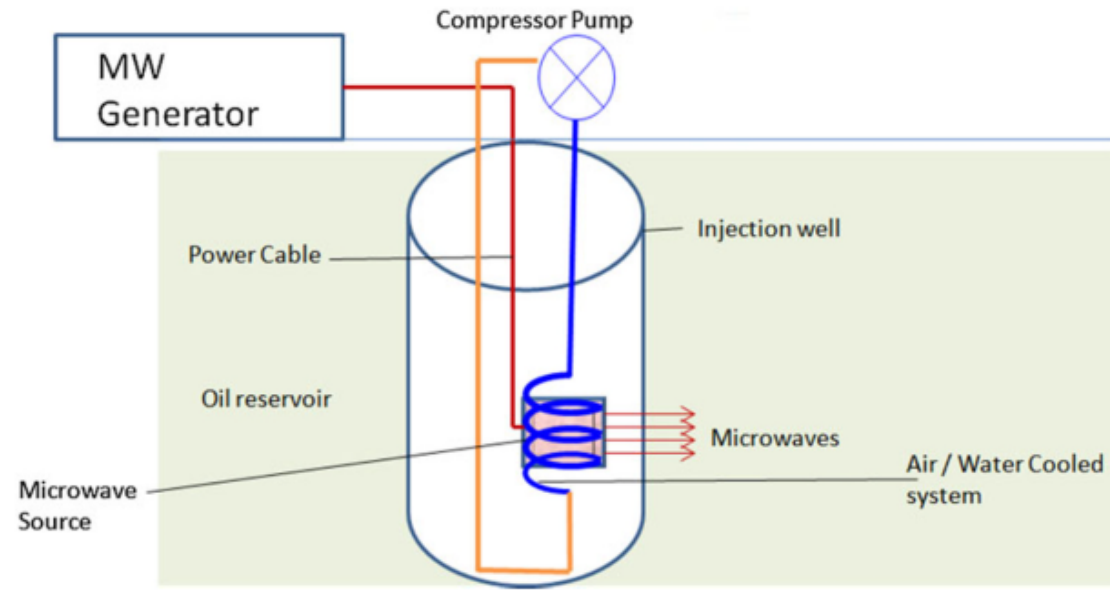

Figure 7 Microwave Based EOR Setup (Rehman \& Meribout, 2012) 


\section{Recoverable Resources, billion bbls}

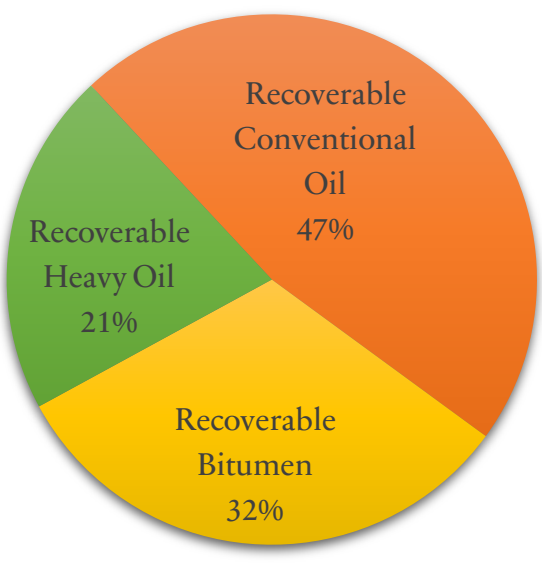

Figure 8 Global Reserve Recoverable (Isaacs, 2011)

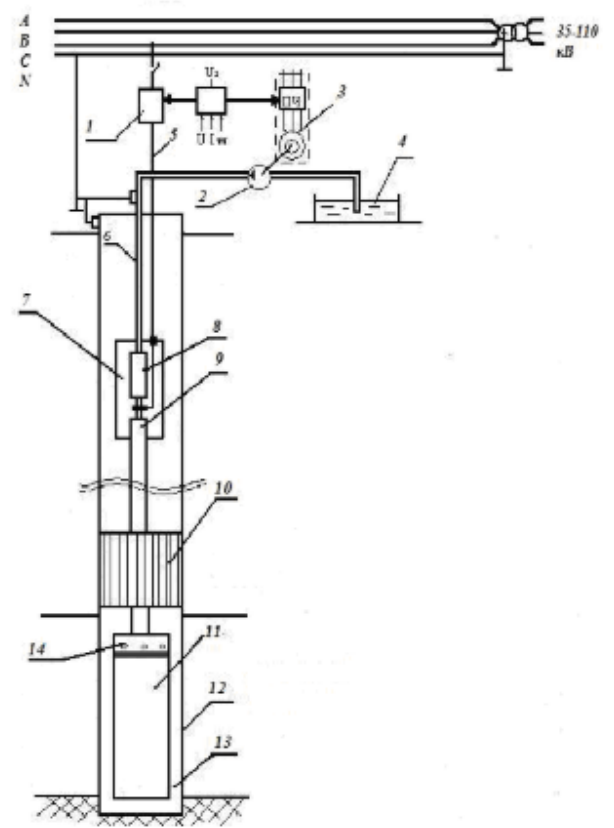

Figure 9 Electrothermal Complex Component 


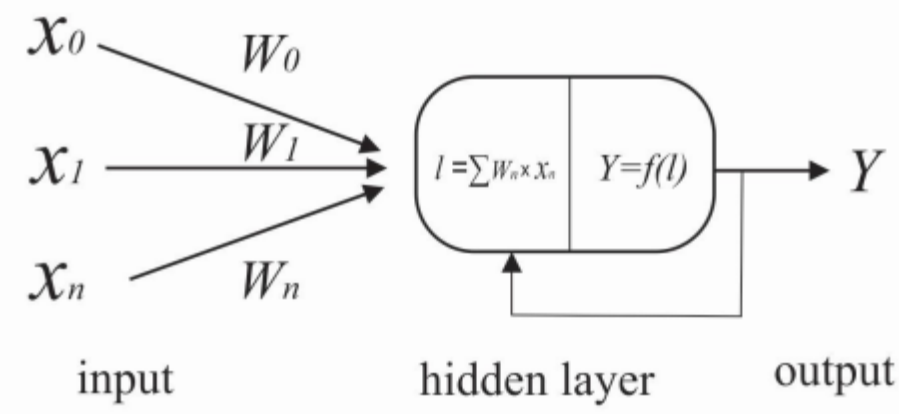

Figure 10 Neural Networks System (Ibrahim et al., 2017)

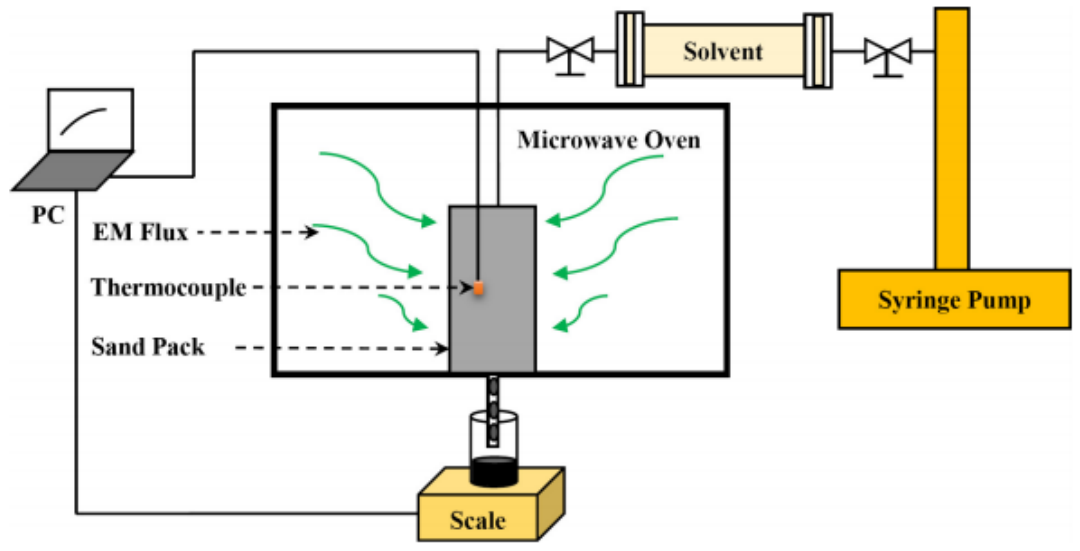

Figure 11 Mechanism of Solvent Extraction (Hu et al., 2017)

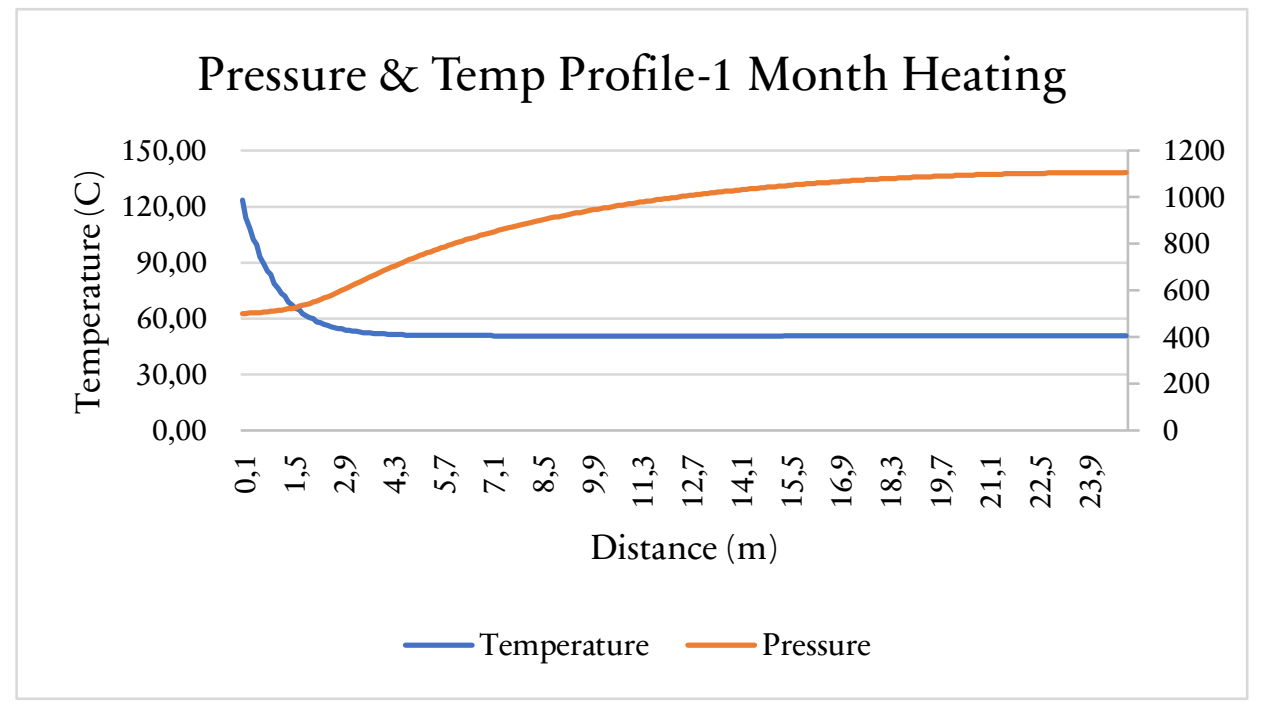

Figure 12 Pressure and Temperature Profile for One-Month $\mathrm{Fe}_{2} \mathrm{O}_{-}$-Electromagnetic Heating (Chandra et al., 2019) 